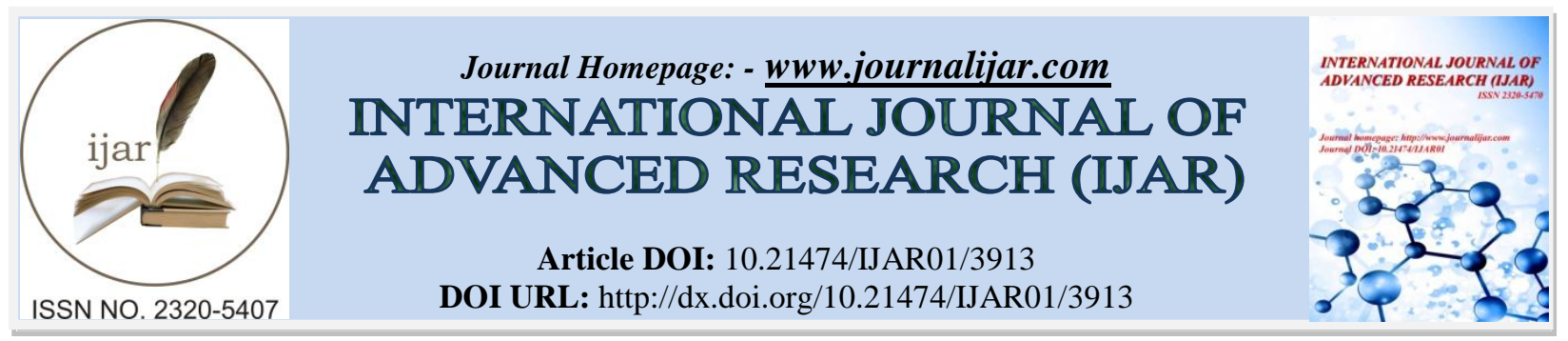

RESEARCH ARTICLE

\title{
APPLICATION OF TOOLS OF THE MONETARY POLICY ON ISLAMIC BANKS IN SUDAN.
}

\section{Dr. Ghassan Farouk Ghandour.}

College of Financial \& Administration-Department of Accounting \& IT, Cihan University/ Sulaiymani, Kurdistan Region Government/Iraq.

\section{Manuscript Info}

\section{Manuscript History}

Received: 16 February 2017

Final Accepted: 11 March 2017

Published: April 2017

Key words:-

Sukuk - Monetary policy tools - Islamic banks.

\section{Abstract}

Monetary policy should be reformulated in a way that is in line with Islamic banking by studying monetary policy tools and their primary and intermediate objectives, which are used for conventional banks to reach final objectives, to know their applicability to Islamic banks, New monetary policy tools that are compatible with the principles of Islamic banking and are capable of achieving two sets of objectives:

1. The objectives of the final monetary policy determined by the monetary authority and choose to achieve rings of primary and intermediate objectives, and be linked to these tools that arm the monetary authority.

2. The objectives of Islamic banks, namely to preserve their capital and maximize their profits, by attracting savings and developing them, and investing them in the legally permissible fields in all sectors of agriculture, industry, trade and services, and providing all banking services with an Islamic template.

Copy Right, IJAR, 2017,. All rights reserved.

\section{Introduction:-}

Monetary authorities in all countries of the world apply monetary policy, under a theoretical framework based on theories and research in the field of monetary policy, which in turn are influenced by the current trends of the economic mainstream, on the one hand, and events on the economic level in general, monetary and financial in particular, Back to the critical theories, we find them in general based on a basic hypothesis based on the traditional banking style, in the mechanism of work and principles and tools. Therefore, the introduction of Islamic banking as a key component of the banking system creates a problematic relationship between monetary policy and Islamic banking in terms of the inadequacy of some of the tools used by monetary policy with the principles of Islamic banking.

\section{Research problem:-}

The inadequacy of some of the tools used by monetary policy with the principles and fundamentals of Islamic banking in Sudan.

\section{Research objectives:-}

The research aims to devise new monetary policy tools that are compatible with the principles of Islamic banking and are capable of achieving the objectives of monetary policy and the objectives of Islamic banks in Sudan.

Corresponding Author:- Ghassan Farouk Ghandour.

Address:- College of Financial \& Administration-Department of Accounting \& IT, Cihan University/

Sulaiymani, Kurdistan Region Government/Iraq. 


\section{Research importance:-}

The importance of research is through the re-formulation of monetary policy in a way that is in line with Islamic banking by studying the tools of monetary policy and its primary and intermediate objectives which are used for conventional banks to reach the final objectives and to know the extent of their applicability to Islamic Sudan banks.

\section{Research Methodology:-}

The researcher used descriptive, analytical and historical methods in preparing the research

\section{Research hypotheses:-}

The ability of Islamic banks in Sudan to adapt some of the tools used by monetary policy to the principles and fundamentals of Islamic banking.

\section{First: Development of Islamic Banks in Sudan:-}

The experience of Islamic banks in Sudan began in 1978 with the establishment of Faisal Islamic Bank of Sudan by special law, followed by three banks.

The Islamization of the banking system in Sudan in full was not in accordance with a flexible and gradual course. In 1981, the transition from the traditional to the Islamic system began with the issuance of a republican decision to prevent specialized banks from using the benefits in their operations and replacing them with Islamic instruments such as Musharaka, Mudaraba and Murabaha.

This decision led the banks in Sudan to choose the easiest and fastest way to apply the Murabaha to finance trade. This led the Bank of Sudan to issue instructions on 08/11/1986 to enforce the credit limits granted in this formula. In 1987, the Bank of Sudan issued a circular to all the banks operating in the Sudan, which is supposed to have been converted into Islamic formulas, demanding that it apply a fixed rate that is defined in advance as "compensatory yield". It was argued that it was intended to compensate depositors for the harm that could be caused to them.

The government criticized this publication as a return to the traditional system. All the existing Islamic banks in Sudan explained that this procedure is in principle inconsistent with the founding documents. It can only be applied if approved by the Shariah Supervisory Board. These bodies then met and discussed the issue, and issued a fatwa that considers that the "compensatory return" is not binding on the banks in Sudan, but has the choice in applying it or continuing its work on the basis of the current situation (Badran, 2015: p165).

In 2000, a reform program was introduced in the Sudanese economy during the period 2000-2005. This program reflected a clear improvement in financial indicators at the level of the banking system: the capital adequacy ratio increased from $7 \%$ to $19 \%$ during the period of the program, the non-performing loans from $16 \%$ to $7 \%$, and the volume of deposits in the banking system rose from 197 billion dinars to 1006 billion dinars (Journal of the union of Arab banks, 2007).

The reform program included the implementation of the dual banking system (Islamic in the north and traditional in the south). The number of banks operating in Sudan in 2010 reached 33 banks, 5 of them specialized banks and 28 commercial banks, including four foreign banks (central bank of sudan).

The Bank of Sudan has taken many steps to develop its supervisory and supervisory capabilities over Islamic banks, including:

- Creating the appropriate legal framework to regulate the relationship between Islamic banks and the Central Bank of Sudan by reviewing the laws and regulations governing banking work (the Bank of Sudan Law, the Banking Regulation Law, the Foreign Exchange Law, and the Khartoum Stock Exchange Law).

- Establishment of the Supreme Authority for Shari'a Supervisory in the Central Bank and the supervisory bodies in banks.

- Setting the foundations and controls for the forms of legitimate financing.

- The application of the Financial Services Board's prudential controls for prudential control, as well as the accounting standards issued by the Accounting and Auditing Organization (IFSB), (AIOFI).

- Compelling banks to disclosure standards.

- Develop mechanisms compatible with the legitimacy of liquidity management and act as lender of last resort.

Assistive institutions have been created such as:

- Takaful Guarantee Fund. 
- Sudan Academy of Financial and Banking Sciences.

- Sudan Financial Services Company, which offers Islamic financial products.

The Sudanese banking system recorded some good indicators in the early years of Islamization. For example, in accordance with the cancellation of the interest system in December 1984, the annual increase in total deposit accounts increased significantly from $35.8 \%$ to $65.9 \%$ in 1985 .

However, as noted above, the transition from the traditional banking system to the Islamic one did not take into account flexibility and gradualism. The abolition of interest in accordance with the Civil Transactions Law of December 1984 made traditional banks apply Islamic banking techniques in a formality in their books and reports under the control of the Central Bank. The latter are opposed to this change in the banking system in this way, which was imposed by a political decision without being preceded by a necessary and detailed study.

The 1983 law provided several Islamic financing formulas for the operations to be applied in financial bank transactions. It also stipulated that banks should allocate part of their resources to grant good loans in order to contribute to the achievement of the country's economic and social goals set out in the constitution.

The relationship of the Islamic banks with the Central Bank of Sudan has passed through several stages. The first stage was characterized by strong control and direct intervention, interspersed with periods of openness and relative liberalization. In recent periods, the role of the Central Bank has focused on policy declaration and monitoring and monitoring of performance through indirect instruments (El Hassan, 1998).

\section{Second: Monetary policy in Sudan:-}

The central bank policies of Sudan are consistent with the fiscal policy axes (the general budget) and the five-year strategic plan of the Central Bank (2007-2011), targeting the optimal size of liquidity to comply with the requirements of economic growth and financial and monetary stability using indirect and appropriate mechanisms for the dual banking system On the safety of the financial sector and to raise its efficiency and continue its antimoney laundering operations.

The policies also aim at spreading banking awareness, increasing rural banking penetration, stimulating savings and mobilizing medium-term resources by encouraging banks to attract investment and savings deposits and reducing the cost of financing in cooperation with the relevant authorities. The policy also aims at tightening coordination and continuous cooperation between monetary, fiscal and other policies related to.

The policies of the Central Bank of Sudan for the year 2010 include the following (Central bank of Sudan):

a. Monetary and financing policy.

b. Foreign exchange policies.

c. Banking and supervisory policies and development of payment systems.

* Policies of regulation and development of the banking system.

- Control policies.

* Policies of payment systems and technology.

d. Currency management policies.

e. Microfinance and microfinance policies and bank financing with a social dimension.

\section{The final objectives of monetary policy in Sudan:-}

Within the framework of the five-year strategic plan of the Central Bank of Sudan (2007-2011), the objectives of the final monetary policy were set as follows (Al-Qusi, 2008: p20):

* Maintaining monetary and financial stability by achieving a single-digit inflation rate by targeting balanced growth in money supply.

* Providing adequate liquidity for the economy to achieve the targeted growth in GDP and increasing the contribution of the private sector to GDP through increased bank financing.

* To achieve sustainable stability of the exchange rate by increasing its flexibility under the managed flexible exchange rate system and considering the transition from unlinking the national currency to a set of currencies and continuing to rationalize the demand for foreign exchange. 
* Improve the efficiency and enhancement of the integrity of the dual banking system (financial centers for banks, performance and assets, address default and protect the sector from the effects of the global financial crisis) and promote and develop Islamic banking formulas.

Based on these guidelines and to achieve these objectives, the policies of the Central Bank of Sudan to be implemented through the Islamic window in the north according to Islamic banking standards, and through a traditional window in the south according to traditional banking traditions under the supervision of the Bank of South Sudan branch.

The intermediate objectives of monetary policy in Sudan:-

The monetary policy announced by the Central Bank of Sudan for 2010 relies on money supply as a mediator target by targeting a nominal growth rate of $22.5 \%$, after the target growth of cash supply was $34 \%$ in 2007 , while maintaining the stability and flexibility of the exchange rate, These intermediate objectives are to achieve a real GDP growth rate of $6 \%$ and maintain an inflation rate of $9 \%$ (Central bank of Sudan).

\section{Monetary Policy Tools in Malaysia:-}

In the early stages and in the absence of indirect instruments of monetary policy, the Bank of Sudan adopted monetary policy and liquidity management on direct instruments, which included literary persuasion and issuing direct directives. In a short period of time, however, he was able to devise and apply indirect tools to Islamic banks, such as Murabaha margins, the client's stake in Musharaka contracts, management margins in Mudaraba contracts, and the legal cash reserve ratio (El Hassan, 1998: p6).

The Central Bank of Sudan has focused on the monetary policy tools that are suitable for both Islamic and conventional banking style. These tools are designed to take into account the specificity of both types. We will shed light on the following tools on monetary policy and how they are directed to the Islamic banks in Sudan (Central bank of Sudan):

\section{Indirect tools of monetary policy:-}

Legal (statutory) reserve ratio:

Islamic banks should keep cash balances with the Central Bank of Sudan in the form of a legal reserve in local and foreign currency at a rate of $8 \%$ of total deposits in local currency and foreign currencies. These include deposits (current deposits, savings deposits and other deposits) as reflected in the weekly position report on deposits and financing at the Bank, Except for investment deposits and the like. Islamic banks also have to keep 10\% of the total current deposits and the like in the form of internal cash liquidity, in order to meet daily customer withdrawals resulting from settlement of transactions ( El Hadi, 2002: p226).

The Central Bank of Sudan has authorized Islamic banks to keep liquid assets in the form of central bank Ijara (Shahab), government participation certificates (Shahamah), other government instruments and non-government instruments, except for shares traded on the Khartoum Stock Exchange, at a rate not exceeding 25\% Existing funding (Journal of the union Arab banks,2007).

\section{Open Market Operations:}

The monetary policy announced in the framework of the strategic plan of the Central Bank of Sudan stated that the Central Bank of Sudan may provide financial support to Islamic banks facing temporary liquidity difficulties through the purchase of securities (sukuk) as determined by the Central Bank.

Sudan is a pioneer in the development of Shariah-compliant financial instruments and serves as a mechanism for liquidity management by trading in open market operations. These instruments do not represent debt but represent a form of participation in profit and loss. As follows:

\section{Certificate of participation of the Central Bank (Shamm) or (CMCs):-}

These certificates were issued in June 1998, a certificate of participation that allows the holder of the participation of the Bank of Sudan and the Ministry of Finance to benefit from the investment in a group of banks and financial institutions. These certificates were approved by the Supreme Supervisory Authority of the banking system and financial institutions as the first Islamic financial instrument Used in open market operations and liquidity management. A fund was established which includes the ownership rights of the Bank of Sudan and the Ministry of 
Finance in partially or wholly owned banks. Based on the Fund's accounting value, a number of certificates have been issued and the value of these certificates is affected The Bank of Sudan and the Ministry of Finance share the profits of the banks and financial institutions that make up the Fund. The Central Bank controls the money supply through open market operations linked to these certificates. If it wants to reduce liquidity, it will ask the banks to submit offers to sell the certificates of participation of the Central Bank.

If the liquidity is to be increased, it will be repurchased and will be at fair value.

The certificates of participation of the Central Bank have been replaced by certificates of lease of the Central Bank (Shehab) or (CICs).

\section{Government Participation Certificates (Shahama) or (GMCs):-}

These certificates have provided adequate tools to finance the government budget deficit without borrowing from the central bank. This certificate entitles the holder to government participation in the profits of a group of companies and institutions with a financial return. They differ from Treasury Bills in that they represent not interestShare in real assets and that its profits represent real profits.

It was followed by government investment certificates (GICs).

These certificates have effectively contributed to the liquidity management of Islamic banks by the Central Bank of Sudan. The number of these certificates reached 11,023,000 certificates at the end of 2009 with a market capitalization of LE 5.511 billion, $35.7 \%$ of which were purchased by banks, $4.3 \%$ of these certificates, the public $25.7 \%$ and investment funds $34.3 \%$ (Annual report of Sudan, 2015).

\section{Discount Rate Mechanism:-}

The Bank of Sudan has abolished its use of interest as a method of banking supervision, as well as discount rates. It has been used as an alternative to the discount mechanism to provide liquidity to banks when needed and to control their ability to grant credit through the cost of obtaining such liquidity by providing financing in accordance with Islamic financing formulas, And to determine its share of the return of such funding in a manner consistent with monetary policy trends in restricting or increasing the volume of credit ( El Hassan, 1998: p14).

The Central Bank of Sudan has allocated two branches for this purpose:

The window of the deficit of liquidity: through which the Central Bank play the role of the last refuge through the financing of Islamic banks that suffer from temporary liquidity crises, and through a set of foundations and controls that ensure the Central Bank of this task, and prevents misuse by any bank.

Investment window: This window addresses the lack of resources of banks by providing the required liquidity for the movement of the economy at the macro level, and investment financing is offered in the form of absolute speculation, while at the micro level, this window plays an important role in addressing the seasonal problem in the demand for funding Banking sector by seasonal sectors such as agriculture, and these sectors are often financed through a restricted speculative formula.

The bank deposit guarantee fund has been established to provide the Islamic insurance service for bank deposits. The fund is jointly financed by the Ministry of Finance, the Central Bank of Sudan and the banks operating in Sudan.

\section{Direct tools of monetary policy:-}

Determining the cost of financing:-

The Bank of Sudan determines the margins of murabaha, the share of the client from the profit of Musharka, and the compensation of the administration in Mudaraba contracts, where the Bank of Sudan specifies a specific range in which these margins are moved. This range is determined and removed through a combination of factors such as macroeconomic indicators such as inflation rates, . Since 2001, the Bank of Sudan has tended to rely on guidance indicators for the margins of operations. It has given banks greater flexibility to move these margins through supply and demand forces, with the possibility of direct intervention if these margins deviate significantly from the index specified in monetary policy (Idris, 2006: p18). 


\section{Credit limits:-}

In the first phase of the Islamization of the banking system (1983-1991), the Bank of Sudan adopted a strict system of total credit ceilings by setting maximum limits for granting loans that are not exceeded by banks except with the approval of the Bank of Sudan. However, the application of the credit limits has negatively impacted the activity which led to a halt in growth in the volume of financing provided by Islamic banks, and therefore stopped accepting new investment deposits, which led to the leakage of such resources outside the banking system.

In the next phase, a more flexible credit ceiling system was introduced, with more emphasis on credit lines through channeling banking finance to the vital sectors.

\section{Credit Framework:-}

Islamic banks may use their resources to finance all sectors and activities except those that are forbidden to be financed. Special attention should be given to priority sectors according to the nature of economic activity in each state. The Central Bank of Sudan issues a detailed publication to guide priorities within the framework of general economic policy. Especially in terms of rural development and support for small projects. The Central Bank of Sudan's policy for 2010 states that, when granting financing, banks should be given the total funding of rural areas by any of their branches at least $70 \%$ The Central Bank of Sudan directs the banks to allocate a minimum of $12 \%$ of the finance portfolio to finance the artisanal sector and the smaller sectors, in order to channel more resources to alleviate poverty.

\section{Determining the relative weight of Islamic financing formulas:-}

The Bank of Sudan has adopted guidelines for determining the types of financing used by banks in operating their resources. This policy is due to the expansion of banks in the use of the Murabaha formula for their ease of dealing and the Bank's ability to determine profit in each Murabaha operation. The monetary policy since 2002 stipulated that the Murabaha formula should not exceed 30\%. This has included monetary policy direct guidance in some cases to prevent the use of some forms of funding as happened to the formula of speculation in absolute monetary policy in 2002 (Majzoub, 2010: p262).Despite this, murabaha still accounts for the largest share of total Islamic financing offered by Islamic banks.The share of Murabaha financing in 2015 at Islamic banks operating in Sudan reached $46.9 \%$ of the total other financing formats:

Table:- Relative weight of the financing formulas of banks operating in Sudan in 2015.

\begin{tabular}{|l|l|l|}
\hline Formula & Financing volume & Weight\% \\
\hline Murabaha & $6,899.7$ & 46.9 \\
\hline Musharka & $1,769.3$ & 12.1 \\
\hline Mudarba & 876.4 & 6.0 \\
\hline Salam & 290.6 & 2.0 \\
\hline Others & $4,845.2$ & 33.0 \\
\hline Total & $14,681.2$ & $\% 100$ \\
\hline
\end{tabular}

Source: Annual report of Sudan 2015

\section{Literary persuasion, rules and direct instructions:-}

The Central Bank of Sudan determines the rules governing the Islamic financing formulas applied by Islamic banks. The Murabaha formula is financed according to the jurisprudential guide issued by the Central Bank of Sudan. The Murabaha is considered a sham if the content of the guide is not complied with. Approved by the Central Bank of Sudan and committed to Islamic banks.

As for the forms of Mudarba and Musharka, each bank is allowed to determine the percentages of Musharka and restricted Mudarba and the margins of the administration, taking into account the controls and foundations of bank financing, and the Central Bank of Sudan encourages banks to use other forms of Islamic financing such as Salam, , and Istisna'a.

The central bank in Sudan shall determine the rules and guidelines required by Islamic banks according to the requirements of monetary policy and the most important directives issued in 2015 (Central bank of sudan):

- The banks must take into consideration that the fees of their banking services are commensurate with the real cost of these services, with the obligation to display them in the media periodically and send a copy thereof to the Central Bank of Sudan. 
* Banks may accept Government Musharaka Certificates (Shahama) and Government Investment Certificates as security for the grant of financing and to the certificate holder only.

* Islamic banks may accept government bonds as collateral to grant financing.

* Directing the methods of collective funding and financing portfolios to finance projects targeted by the general budget for 2015.

* Banks should focus on the feasibility of the project and the client's position rather than focus on the mortgages and guarantees when granted to finance.

To ensure the effectiveness of the tool of moral persuasion, the Central Bank of Sudan provides incentives to cooperating banks to finance priority sectors, medium-term financing, and socially-funded financing. These incentives are as follows:

1. Reduce the cost of funding provided by the Central Bank.

2. Participation in financial portfolios.

3. Preference in the sale and purchase of Sukuk and other securities.

4. Provide guarantees to the banks concerned in accordance with the principles determined by the Central Bank.

5. Reduction of the Legal cash reserve ratio.

Third: Lessons learned from the Sudan experience in guiding monetary policy for Islamic banks:-

The experience of the Sudan in the management of monetary policy and its guidance to Islamic banks is a pioneering experience in the integration of innovative monetary instruments compatible with Islamic banking and their efficiency. The experience of Sudan is a practical experience that demonstrates the possibility of formulating the relationship between the Central Bank and Islamic banks in the manner in which Monetary policy with high efficiency to reach its objectives, without hindering Islamic banks or adversely affect them, especially in overcoming the problem of supplying Islamic banks with liquidity and the creation of alternatives to the discount mechanism, while providing Islamic financial instruments And to preserve the authenticity of Islamic banks through the provision of central Shari'a control. The experience of Sudan, however, is not without some drawbacks:

The Sudanese experience in the field of Islamic financial engineering industry may be quick to take the necessary measures without prior and in-depth study of what can result from any step in the development of the financial system or the creation of financial tools and products. The Sudanese experience is driven largely by the political, while the growth of the financial engineering industry requires feasibility studies of costs and benefits rather than political decisions.

The weakness of the macroeconomic framework, the Sudanese economy suffers some of the structural problems, and as is well known, the financial system is linked to the system of macroeconomic is affected by and affects it, and an efficient economic system is a prerequisite for an effective financial system that allows the development of financial institutions and then local Islamic financial engineering industry, as the Islamic financial engineering products industry in Sudan are particularly geared to the domestic market, targeted for testimonies of pride, then managing domestic liquidity, and financing operations geared to local sectors ... as well as with respect to Islamic banking transactions in the capital markets are almost completely non-existent.

\section{Forth: Conclusions and recommendations:-}

\section{Conclusions:-}

In order to apply monetary policy to the Islamic banks, it is necessary to benefit from the experiences of other countries in this field, especially countries that have transformed their entire banking system into the Islamic banking system as in Sudan. The experience of Sudan in the field of monetary policy management within the framework of Islamic banking system A pioneering experience through the application of Islamic alternatives to the discount mechanism through Islamic financing formulas through the window of liquidity deficit and investment financing, and the development of Islamic financial instruments that are consistent with Islamic law such as the participation certificate of the Central Bank (Shamm), government participation certificate (Shahama) These financial instruments have played an active role in activating open market operations as a monetary tool used by the Central Bank towards Islamic banks, as well as using many direct tools such as pricing of banking services, determining the cost of financing, Relative to Islamic financing formats. 


\section{Recommendations:-}

The importance of reviewing the strategy of monetary policy in any willing to apply Islamic banking style state, and requires the use of new monetary tools compatible with Islamic banking style, through the development of a system for the exchange of liquidity between Islamic banks and the Central Bank as an alternative discount mechanism, with the open market activation by finding Islamic financial market, while allowing Islamic banks to issue Islamic bonds with the strict control by the monetary authority, to be truly representative of the real assets or actual financing operations, and the use of these instruments in the open market operations towards Islamic banks, Wei Be here to take advantage of Sudan's experience in activating the open market operations through a variety of government securities Sharia-compliant.

\section{References:-}

1. Ahmed Jabir Badran: Central Banks and their role in the supervision of Islamic banks, Dar Al-Masirah, 2015.

2. Saber Mohamed El Hassan: Monetary Policy in Contemporary Islamic Application, Research Presented to the Symposium on Contemporary Islamic Economic Applications, Casablanca, Morocco, 1998.

3. Journal of the Union of Arab Banks October 2007, Supplement No. 323.

4. The official website of the Central Bank of Sudan, http://www.cbos.gov.sd/arabic/banking_system.htm

5. Al-Qusi, Abdul-Moneim, Sudan's Experiences in Monetary Policy, Working Paper for the World Conference on Islamic Economics, 1/4/2008, King Abdulaziz University, Riyadh.

6. Monetary Policy for the Year 2002 in Sudan, Journal of the Union of Arab Banks, Issue: 262, September 2002.

7. Monetary policy instruments in Sudan between the traditional and Islamic systems, Union of Arab Banks, No. 238.

8. Annual Economic Report 2015, Central Bank of Sudan.

9. Mohamed El Hadi, Saleh, Asset Management and Financing Risk in Traditional and Islamic Banking, Union of Arab Banks, 2002.

10. Idris, Youssef Osman et al., How to determine the margin rates of murabaha banks, series of studies and research, Central Bank of Sudan, Khartoum, 2006.

11. Ahmed, Ahmed Majzoub, Application of Islamic Formulas in the Banking System and its Impact on Monetary Policy, Islamic Fiqh Research Center, www.kantakji.com/fiqh/Files/Economics/262.doc

12. Bank of Sudan policies published on the official website of the Central Bank of Sudan.

13. Policies of the Islamic banking system in Sudan published on the official website of the Central Bank of Sudan. 